\title{
Articles
}

\section{Years of Criminal Justice in Europe}

\author{
Hans G. Nilsson ${ }^{\star}$
}

\begin{abstract}
This article contains a journey through the European landscape of criminal law, as seen by the author during his 25 years of work for European institutions, first 10 years in the Council of Europe and then 15 years in the Council of the European Union. It also contains an analysis of the difference between intergovernmental work and the Community method including some comments on the criminal law chapter of the Lisbon Treaty.
\end{abstract}

\section{Introduction}

There are very few people who have had the opportunity and the chance, like I did, to experience the developments in criminal justice in Europe in the past 25 years at close range. Indeed, the development in the past years of a real, genuine, European Criminal law has been astonishing, beyond belief and certainly not predictable; this has been due to a great extent to the incorporation of the criminal law dimension into the legal framework of the European Union since 1 November, 1993, as a result of the entry into force of the Treaty of Maastricht. With the Treaty of Amsterdam, which followed on 1 May, 1999, the pace became accelerated.

Cooperation on criminal law has always been done on a step-by-step basis, as with almost all other European cooperation, be it within the framework of the Council of Europe or in the framework of the European Union. Sometimes the steps have been small; sometimes they have been greater (viz setting up of monitoring mechanisms like GRECO and Moneyval; the European Arrest Warrant and Eurojust; QMV and co-decision under the Lisbon Treaty, etc.).

\section{Work within the Council of Europe}

The Council of Europe has worked on European Criminal Law for more than 50 years. The European Convention on Extradition ${ }^{1}$, which replaced a number of bilateral treaties at the time it was adopted, was already signed in 1957. The

\footnotetext{
* By Hans G Nilsson, Head of Unit, Fundamental Rights and Criminal Justice, Council of the European Union. Academic lecture given on 26 January, 2012, in view of the author's promotion on 27 January, 2012, to Jur Dr honoris causa at the University of Uppsala. The opinions expressed are those of the author and not necessarily those of the Institution which he serves.

${ }^{1}$ Council of Europe, European Convention on Extradition, 13 December 1957, Paris, CETS 024.
} 
European Convention on Mutual Legal Assistance in Criminal Matters ${ }^{2}$ was adopted in 1959, and it apparently replaced more than 200 bilateral treaties at the time of its adoption. The European Committee on Crime Problems has developed over a hundred Recommendations (non-binding) and 34 Conventions and Protocols (binding when they have been ratified by the Member States).

First and foremost, the author wishes to express the opinion that he firmly believes the work of the Council of Europe in the field of Criminal Law has been of an extraordinary quality and an inspiration for the work of the $\mathrm{EU}^{3}$. The Council of Europe has developed instruments that the Union's Member States are still using, not only in relation to third countries, but also among themselves. The Recommendations developed by the Council of Europe are a source of inspiration and reflection at national level in a number of areas of criminal justice.

At the time - around 1987 - of the work on the Single European Act, when the Community Member States, outside the legal framework of the European Community, but in the framework of the European Political Cooperation, sought to develop some five criminal law Conventions, none of which ever entered into force, the Officials of the Council of Europe, including the paper's author at the time, had a very negative view of work of the EU in the field of criminal law - why was the European Economic Community trying to stride into the field of Criminal Law which was entirely alien to the objectives of the Community which was considered to be an economic cooperation mechanism? This, it was thought, should be left to the Council of Europe, which had both the substantive knowledge and the procedures to deal with this issue - which, in addition, was intimately linked with the European Convention of Human Rights ${ }^{4}$ and the case-law of the Court, and in particular Articles 5 and 6.

Since that time, 25 years ago, there has always been a tension between the criminal law work of the Union and of the Council of Europe. A tension, a competition or a healthy relationship? Supplementary, complementary or competing interests? Probably a bit of everything.

\section{Intergovernmental method vs "Community method"}

Looking at it from the point of view of the Council of Europe, it would no doubt be better, and create maximum legal certainty, if only instruments of the Council of Europe could be adopted and would apply in all 47 Member States of the Council of Europe in the field of criminal law.

\footnotetext{
${ }^{2}$ Council of Europe, European Convention on Mutual Legal Assistance in Criminal Matters, 20 April 1959, Strasbourg, CETS 030 .

${ }^{3}$ For an exhaustive examination of the relationship between the two European bodies, see Marina Kolb, Academic dissertation, University of Vienna, From Friend to Foe? Shedding light on the Interorganisational Relationship between the EU and the Council of Europe, June, 2011.

${ }^{4}$ Council of Europe, Convention for the Protection of Human Rights and Fundamental Freedoms, 4 November, 1950, Rome, CETS 005.
} 
However, this would ignore some important advantages of adoption of criminal law instruments in the EU context. First, the EU mechanisms are much more productive; only during the Amsterdam Treaty (10 years) the Union has adopted some 40 Framework Decisions or Directives (there are about 5 of these) in the area of criminal law. Compare this to the 34 instruments adopted during 50 years of the Council of Europe. Secondly, the EU instruments are binding on all the Member States of the Union (with the exception of UK, IE and DK, although the first two have voluntarily made most of them binding after Lisbon). Thirdly, the European Commission will be able to take the EU Member States to the European Court of Justice in case of non-implementation or application of them (for Framework Decisions as from 1 December, 2014). Fourthly, for the interpretation of these instruments, there is the possibility, and often the obligation, for national courts to request preliminary rulings from the Luxembourg Court on the interpretation of the EU instrument in question. Fifthly, the EU may adopt legislation nowadays by Qualified Majority Voting and with the European Parliament as a co-legislator.

These five parameters also show the differences between the intergovernmental method and the "Community Method", as it is usually described. In particular, the absence of a Commission, a directly elected Parliament and a Court being able to give rulings of interpretation on Strasbourg criminal law is a major difference.

In the period of the Amsterdam Treaty, the Council of Europe has adopted 10 Conventions. It is too early to assess whether or not they are all successful since they require ratifications by the Member States and we know that this may take a long time. In addition, 21 Recommendations have been adopted in a number of fields. Whether they have been implemented or not is, however, uncertain. In any case, these Recommendations will serve as reference texts for all Member States of the Council of Europe, and thus for the Union Member States as well.

When the author joined the Secretariat of the Council of Europe in September 1986, he was immediately put in charge of three files; one which was the final stages of a 5 year negotiation of a Recommendation concerning the Simplification of Criminal Justice, which led to the adoption of Recommendation $\mathrm{Nr} 87$ (18) of the Committee of Ministers on 17 September, $1987^{5}$. The second file was on the Ministerial Conference of the Pompidou Group on Drugs, where in Norway, Oslo, they would deal with, among other things, tackling the proceeds of drugs trafficking, which would include a topic called money laundering; this was not really known in most Member States and it was certainly not a crime in many of the Member States of the Council of Europe, with the exception of Italy and the UK. The third file was on computer-related crime. These three files illustrate how the Council of Europe has always been in the forefront of advancing criminal law internationally.

\footnotetext{
${ }^{5}$ Council of Europe: Committee of Ministers, Recommendation R (87) 18 of the Committee of Ministers to Member States concerning the Simplification of Criminal Justice, 17 September, 1987.
} 


\section{Simplification of criminal justice}

On the simplification of criminal justice, the main objective of this Recommendation was to tackle the delays in criminal proceedings and to propose alternative ways of dealing with certain types of crime, in particular those carrying minor penalties. It proposes to resort to the principles of discretionary prosecution, making use of summary procedures in minor cases, out-of-court settlements and simplified procedures. It also deals with the simplification of ordinary judicial procedures.

At the time, the author, rather uncertain whether the work that was done in the Committee that drafted the Recommendation would be useful, but when the Berlin Wall fell and all Central and Eastern European countries had to reform their Codes, including the Code of Criminal Procedure, it turned out that this Recommendation was seen as a Common Denominator and a model for how to build up new Court systems. Between 1990 and 1996, the author participated in many seminars and workshops in Central and Eastern Europe to discuss the Recommendation and its guiding principles and realised that many governments and parliaments in their work on reform looked to the Council of Europe for guidance.

\section{Money laundering}

The second topic, dealing with money laundering, had been decided by the Ministers of the Pompidou Group at a Ministerial conference in Oslo in 1986. Since the decision was taken within that framework, it was by necessity limited to money laundering of the proceeds from drugs trafficking. When the European Committee on Crime Problems (CDPC) was asked in 1987 to draw up terms of reference of the expert Committee that was charged with drawing up the Convention, the decision was to enlarge the scope of the future Convention to an "all crimes" basis. This also included the possibility of making reservations for those Member States of the Council of Europe that did not wish to go so far at the time.

At the same time, negotiations were beginning to take form in Vienna, in the framework of the UNODC, for what was to become known as the 1988 Vienna Drugs Convention ${ }^{6}$, where the author was participating as an observer of the Council of Europe. The negotiations in Vienna were interrelated, where an Italian Ministry of Justice official and former judge, Gioacchino (Gino) Polimeni, chaired both the Council of Europe Committee and the so-called Committee of the Whole in Vienna. Julian Schutte, a Dutch Ministry of Justice official, was also an active participant in both negotiations which were concluded by an Intergovernmental conference on 20 December, 1988. Almost at the same time, the Council of Europe concluded its negotiations on Convention ETS $141^{7}$, namely the Convention on money laundering, search, seizure and confiscation of the proceeds from crime. This

\footnotetext{
${ }^{6}$ UN Economic and Social Council (ECOSOC), United Nations Convention Against Illicit Traffic in Narcotic Drugs and Psychotropic Substances, 19 December, 1988, Vienna.

${ }^{7}$ Council of Europe, Convention on Laundering, Search, Seizure and Confiscation of the Proceeds from Crime, 8 November 1990, Strasbourg, CETS 141.
} 
Convention, which has been ratified by all Council of Europe Member States, entered into force in 1993, when 3 Member States had ratified it.

Money laundering became a popular subject with governments, in particular with Finance Ministries, when the G8 set up the Financial Action Task Force against money laundering and drafted 40 Recommendations on the subject in 1989. The author also became the Council of Europe observer in that Committee, which led to the development of the Council of Europe's own "FATF" which was to become the Moneyval Committee of the Council of Europe.

The principal idea behind the FATF, and later the Moneyval, was that peer pressure combined with self and peer evaluations would ensure better implementation in the legally, technically and politically sensitive area of money laundering and keeping financial systems clean from the proceeds of drugs trafficking and organized crime. This was an idea that was also later applied, in 1997, when the EU set up its own peer pressure mechanism in the area of organized crime, following the 1997 High Level Report on organized crime, adopted by the Amsterdam European Council. An additional argument at the time was that this system could compensate for the fact that the Union in the third pillar had not had any infringement procedure as is the case in the first pillar.

When Moneyval was set up within the Council of Europe, the main argument towards the FATF was that the non-FATF members of the Council of Europe, which included the Russian Federation and Ukraine, could become the subject of the peer evaluation mechanism under the same conditions as the FATF mechanism itself. It took some time and effort to convince the FATF that this would be possible, and it was no small task to convince the CDPC at the Council of Europe to integrate the system into its working structures. The best argument at the time (and it is still true) was that most non-members of the FATF would probably never become members of the FATF.

\section{Peer evaluation}

Since that time, thinking has developed in relation to the system of peer evaluation and one may even now find a clear reference to the system in Article 70 TFEU. When the first Round of mutual evaluations - on mutual legal assistance in criminal matters - was set up within the Council, the Commission did not even want to participate because it considered that it infringed its own prerogatives of evaluation and assessment of implementation. In fact, this has later been recognised by Commission officials to have been a strategic mistake, and the Commission has taken an active and constructive part in the other four Rounds (on drugs cooperation, on exchange of information, on the European Arrest Warrant and on financial crime). There is no doubt that the 6th Round on national practical implementation and operation of Eurojust cooperation will become an important factor for future initiatives of the Commission. 
The system of peer evaluation was apparently originally an idea that was used by the OECD to assess economics on the ground. Since the FATF was set up within the framework of the OECD with a strong element of input from Ministries of Finance, it was natural that the FATF adopted this method, later substantially refined by the FATF itself, by the Council of Europe in the framework of Moneyval and GRECO - the Group of States against corruption -, the OECD as regards corruption in international business transactions and which is sought now to be used by the UN itself as regards the UNCAC (corruption) and the UNTOC (the Palermo Convention regarding organized crime). This has no doubt led to a certain "evaluation fatigue" in the Member States but it has no doubt proven useful to seek to create a better and more level playing field. The great advantage as compared to normal infringement procedures in the EU is that it is based on a positive approach by learning from each other, putting peer pressure on making changes and that entire systems - and not only parts - can be evaluated. The disadvantage, at least in the way it has been done in the EU, is that the follow-up has been weak. This is to a great extent due to a lack of resources, but probably also to the fact that any follow-up would require an amount of (political) name and shame which may not always be easy in a closely knit club.

\section{Computer crime}

The third topic on which the author worked from the outset in the Council of Europe was computer crime. This was also an example of how the Council of Europe was ahead of its time and was breaking new ground in criminal law. The work had started in the framework of the OECD in 1982, but was taken over by the Council of Europe in 1986. This work led to Recommendation No R (89) 9 on computer-related crime ${ }^{8}$, Recommendation No R (95) 13 concerning problems of criminal procedure law connected with information technology ${ }^{9}$ and ETS $185^{10}$; the Convention on cybercrime and its Additional Protocol on racism and xenophobia $^{11}$. The USA and Canada were observers, among others, already in the expert Committee that drafted the Recommendation from 1989, under the Chairmanship of the famous German Ministry of Justice official, Manfred Möhrenschlager, who knew better than many experts their own legislation and Court practice. The US has ratified the Cybercrime Convention and is a strong proponent of its ratification worldwide. This will unfortunately not happen - in the international community,

\footnotetext{
${ }^{8}$ Council of Europe: Committee of Ministers, Recommendation R (89) 9 of the Committee of Ministers to Member States on Computer-related Crime, 13 September, 1989.

${ }^{9}$ Council of Europe: Committee of Ministers, Recommendation R (95) 13 of the Committee of Ministers to Member States concerning Problems of Criminal Procedure Law connected with Information Technology, 11 September, 1995.

${ }^{10}$ Council of Europe, Convention on Cybercrime, 23 November, 2001, Budapest, CETS 185.

${ }^{11}$ Council of Europe, Additional Protocol to the Convention on Cybercrime, concerning the Criminalisation of Acts of a Racist and Xenophobic Nature committed through Computer Systems, 28 January, 2003, Strasbourg, CETS 189.
} 
viz the UN, the Council of Europe is seen as a regional organisation and not many States are willing to ratify a Convention in which they have not participated in the negotiations. This is one of the reasons why some preparatory work has now started in Vienna which no doubt will lead to a UN convention in the field in some 5 years from now. One may hope that this will not lead to a watering down of the relatively efficient system of cooperation set up by the Cybercrime Convention.

It should be noted that the work of the Council of Europe has to a great extent influenced the EU Framework Decision on attacks against information system ${ }^{12}$ and the draft Directive on the same subject ${ }^{13}$ which is currently under negotiation with the European Parliament. This draft Directive, which will repeal the Framework Decision, is hopefully to be adopted before the end of the year. The Recommendation from 1989 has no doubt influenced national legislation in that it contained guidelines for national legislatures, but it is only a Recommendation and the author still finds himself in Council working parties, 25 years later, discussing whether or not it should be necessary to break a password or not in order to have committed a hacking offence. The issue of jurisdiction has not been solved either in the author's opinion they have failed to create an own jurisdictional concept appropriate for certain types of computer-related offences which can be prepared and committed in the territory of one country while using servers in 5 others and create damage in one hundred other countries. Clearly, normal jurisdictional concepts are not appropriate in many of these cases.

\section{Corruption}

At the beginning of the 1990s, the author also became interested in the work that was ongoing in the framework of the OECD on corruption in international business transactions. The work was largely promoted by the USA which had failed to create a level playing field for its own business in the framework of the UN. The USA had already adopted its Foreign Corrupt Practices Act in the 1970s but this was not followed through by other trading and investment parties.

It was felt in the Council of Europe that the approach of the OECD was too narrow - corruption was the antithesis of human rights and threatened the Rule of Law and Democracy - the founding values of the Council of Europe. The author participated in the organisation of the 1994 Ministeral Conference of the Ministers of Justice in La Valletta, Malta, where it was decided to set up a multidisciplinary group against corruption (GMC), which would later become GRECO. The idea at the time was to set up a so-called partial agreement - "the Scalfaro Group" on the same basis as the Pompidou Group - but at the end the Italian President Mr Scalfaro could not lend his name to the group for various reasons. Finally it was the Italian

\footnotetext{
${ }^{12}$ Council Framework Decision 2005/222/JHA of 24 February, 2005, on attacks against information systems [2005] OJ L 69, p. 67.

${ }^{13}$ Proposal for a Directive of the European Parliament and of the Council on attacks against information systems and replacing Council Framework Decision 2005/222/JHA.
} 
Minister of Justice who formally proposed it to his colleagues. It should be remembered that we were in the middle of the Mani Pulite actions in Milano which began in February 1992. One may conclude that it was a win-win situation both for the Council of Europe and for Italy, so the GMC was set up. It drafted the criminal law convention against corruption ${ }^{14}$, the civil law convention $^{15}$ - a very innovative instrument, which has been followed by a EU Framework Decision ${ }^{16}$ - Resolution (97) $24^{17}$ on the 20 guiding principles in the fight against corruption, which became the basis for the GRECO peer evaluation. The first Chair of the GMC became Judge Vincent de Gaetano, who was later to become Chief Justice of Malta. A Senior President of the Rome Court of Appeal became Vice-President.

The author was also Secretary to other Committees that developed Conventions on Illicit Traffic by Sea, Implementing Article 17 of the 1988 Vienna Drugs Convention $^{18}$, and the Convention on the Protection of the Environment through Criminal Law ${ }^{19}$, under the Chairmanship of Gunnar Björne, who was later to become President of the Swedish Supreme Administrative Court. The former Committee, once again chaired by Gino Polimeni, led to the author's involvement in the highly complex Law of the Sea Conventions, including the Montego Bay Convention $^{20}$. The environment Convention was to follow the author to the EU, first in the form of a Framework Decision which was annulled by the Court of Justice in the landmark Case C-176/0, and then in the Directive which was adopted in $2008^{21}$. Here again, it can be noted that the Council of Europe work was the basis for the EU in the adoption of its two instruments.

Being Secretary to the CAHDI when Hans Corell was its Chair prior to him becoming the jurisconsulte of the UN, and to the Committee that developed a Protocol to the Convention on Nationality, made the author broaden his views on public international law.

The landmark judgment in the environment $\operatorname{case}^{22}$ is one where even I am critical towards the decision of the Court of Justice. The Court was no doubt fully aware of the discussion that been ongoing for decades of whether or not the Union could adopt criminal law in the first pillar. Against the advice of 11 intervening governments, the Court said that it was possible, although it clarified in the socalled ship-source pollution case (C-440/05) that it was for the Member States to

\footnotetext{
${ }^{14}$ Council of Europe, Criminal Law Convention on Corruption, 27 January, 1999, Strasbourg, CETS 173.

${ }^{15}$ Council of Europe, Civil Law Convention on Corruption, 4 November, 1999, Strasbourg, CETS 174.

${ }^{16}$ Council Framework Decision 2003/568/JHA of 22 July, 2003, on combating corruption in the private sector [2003] OJ L 192, p. 54.

${ }^{17}$ Council of Europe: Committee of Ministers, Resolution (97) 24 of the Committee of Ministers to Member States on the Twenty Guiding Principles for the Fight against Corruption, 6 November, 1997.

${ }^{18}$ Council of Europe, Agreement on illicit Traffic by Sea, implementing Article 17 of the UN Convention against Illicit Traffic in Narcotic Drugs and Psychotropic Substances, 31 January, 1995, Strasbourg, CETS 156.

${ }^{19}$ Council of Europe, Convention on the Protection of Environment through Criminal Law, 4 November, 1998, Strasbourg, CETS 172.

${ }^{20}$ UN General Assembly, United Nations Convention on the Law of the Sea, 10 December, 1982, Montego Bay.

${ }^{21}$ Directive 2008/99/EC of the European Parliament and of the Council of 19 November, 2008 on the protection of the environment through criminal law [2008] OJ L 328, p. 28.

22 Case C-176/03
} 
decide on the type and level of sanctions. In my opinion, this should be done by treaty changes and not by case-law in this extremely sensitive area. It is fortunate that the Lisbon Treaty to a great extent has clarified the situation, although the Treaty has not clarified everything and even created new lines of division/discussion.

The work of the Council of Europe also made me look into other areas of law where, once again, the Council of Europe was doing pioneering work. One such area was work that led to Recommendation No R (92) 1 on the use of analysis of DNA within the framework of the criminal justice system ${ }^{23}$. This Recommendation was very controversial since it contained principles relating to data protection and storage of samples and data. Four governments reserved their right under article 10.2.c of the Minister's Deputies to comply or not with the whole or part of the Recommendation.

Another interesting Recommendation was No R (92) 17 concerning consistency in sentencing ${ }^{24}$ where Professor Andrew Ashworth, Jur Dr h.c. at the Uppsala University in 2003, sought to bring together professors, judges, prosecutors and ministry officials on rationales for sentencing, penalty structures, aggravating and mitigating factors, taking into account previous convictions, giving reasons for sentencing etc. Clearly a challenging work when the Council of Europe had started to enlarge to Central and Eastern Europe and the divisions on sentencing policy was, and still is, considerable in the rest of Europe. Another Recommendation connected therewith was Recommendation No (94) 12 on the independence, impartiality and efficiency of judges ${ }^{25}$ where the country that is reputed to have the most independent judges controversially had the most problems in adopting the Recommendation.

When the author arrived at the Council of Europe in 1986, it had 21 Member States: the 15 Member States of the EU, minus Finland, which was only allowed to join fully in 1989 in the age of Glasnost and Perestroika, in addition to Turkey, Malta, Cyprus, Norway, Switzerland, Iceland and Liechtenstein. When the author left 10 years later, the Council of Europe had 39 Member States. Hungary had been the first country of Central and Eastern Europe to join on 6 November, 1990; the author was the Head of a Council of Europe delegation in Budapest on that day, and recalls how they were received with a standing ovation in the beautiful Hungarian Parliament.

Apart from the work in intergovernmental Committees of experts, travel all over the world to represent the Council in matters relating to money laundering, corruption, computer crime and criminal justice in general, the author had also

\footnotetext{
${ }^{23}$ Council of Europe: Committee of Ministers, Recommendation R (92) 1 of the Committee of Ministers to Member States on the Use of Analysis of Deoxyribonucleic Acid (DNA) within the Framework of the Criminal Justice System, 10 February, 1992.

${ }^{24}$ Council of Europe: Committee of Ministers, Recommendation R (92) 17 of the Committee of Ministers to concerning Consistency in Sentencing, 19 October, 1992.

${ }^{25}$ Council of Europe: Committee of Ministers, Recommendation R (94) 12 of the Committee of Ministers to Member States on the Independence, Impartiality and Efficiency of Judges, 13 October, 1994.
} 
begun, together with all of his colleagues in the Directorate of Legal Affairs and in the Directorate of Human Rights, to advise governments in Central and Eastern Europe on legislative reform, both procedural law, criminal law and civil law. The so-called Demosthenes programme became a success since it responded to the requests from newly formed democracies. It also contributed to more than 150 days of travel away from home, per year.

The author's 10 years in the Council of Europe ended in 1996 - Sweden had become a Member State of the EU one year before - and the author would be dealing with civil and criminal judicial cooperation for the next 15 years to come. Fundamental rights became another interesting topic with the advent of the Charter of Fundamental Rights and the negotiations on the accession of the Union to the Convention of Human Rights, which are still on-going.

\section{The Council of the EU}

The development of EU cooperation since the Treaty of Maastricht, and in particular since the Treaty of Amsterdam has been astounding. In the eyes of many spectators in Sweden it has been too far reaching: too much, too quickly and too much interference in national law.

The author is definitely not of this view.

If we compare the intergovernmental cooperation in the Council of Europe to the EU cooperation that there is today, definite advantages in relation to the EU can be seen, in particular with what has happened since Amsterdam. In the Council of Europe, an intergovernmental Committee develops a Convention that may or may not be ratified, a Recommendation that may or may not be implemented or a report that may or may not be read. Council of Europe reports are certainly interesting from a theoretical perspective (read, for instance, the one on jurisdiction) but they do not change much in practice. Compare this to the Community method with a proposal that takes into account the common good after having examined the situation on the ground, and where the Union has means to ensure that what one has agreed will also be implemented; if necessary through a Court order. In terms of legitimacy, nowadays, the criminal law legislation in the EU is developed together with the directly elected European Parliament - the Union has de facto a bicameral system where the two chambers, the Council and the European Parliament have to agree on every comma of the legislative act. The Parliamentary Assembly of the Council of Europe does not fulfil that function in the same manner.

As noted previously, the amount of legislative action during the ten-and-a-half years of Amsterdam has been impressive - it is with implementation that the Member States (not the Union) have been their weakest. The transitional rules in Protocol $36^{26}$ and the gradual development of Directives (and even Regulations) will correct this over time. 
What has contributed to this legislative output of the Union during the Amsterdam Treaty? A number of factors of an external, internal and institutional character may be singled out.

The globalisation or, at least, Europeanisation of crime has no doubt been an important factor. Free movement of persons has also meant increased mobility of serious crime, what often is discussed as cross-border itinerant crime, and a corresponding need for more effective cooperation across the (internal) borders of the Union and often approximated/ harmonised legislation and procedures. Criminal law is not only a compensatory measure to the abolition of borders but a policy in its own right.

\section{Programming the work}

The Adoption of the 30 very practical Recommendations of the High Level Group on organised crime in 1997, contributed largely to the development of concrete measures to begin the implementation of the Treaty objective of creating the Area of Freedom, Security and Justice. The very balanced Tampere conclusions in 1999, also largely contributed to this development. The fact that mutual recognition was pronounced to become the cornerstone of judicial cooperation had an impact on the entire period and has since been incorporated into the Treaty of Lisbon. The two subsequently adopted programmes of measures adopted by the Council in the year 2000, largely contributed to a concrete realisation of the principle of mutual recognition - the criminal law programme contained 24 measures, most of which have been implemented today.

\section{Developing the Area of freedom, security and justice}

The fact that the Commission, which began as a Task Force in the Secretariat General, developed into a fully fledged Directorate General (later into two) cannot be underestimated either: the Commission's proposals increasingly improved, as did the quality of the impact assessments, and the financing programmes started to work better and better. The staff numbers were increased, and from 5 persons in the beginning, the Commission counts on more than 600 staff today. When the financing programmes were set up towards the end of the 1990s, they were given some 2 million euros. Today, the justice and fundamental rights programme alone are proposed to have 800 million euros, and the asylum, immigration and internal security programmes 10 times that much.

The General Secretariat of the Council began as a small Directorate General with a few people, but is now one of the larger Directorate Generals with some 80 persons and the full resources of each rotating Presidency working with gusto each 6 months. The resources and knowledge of the European Parliament still need to

\footnotetext{
${ }^{26}$ Protocol (No 36) on Transitional Provisions, [2008] OJ C 115, p. 322.
} 
be built up (only 10 administrators are dealing with the entire JHA area), but they are increasing steadily.

Finally, the European Court of Justice, which from the beginning under the Maastricht Treaty had no powers in principle in criminal law, had gradually gained powers in 18 countries by the end of the Amsterdam Treaty to give judgments after requests for preliminary rulings. After a transitional period under the Lisbon Treaty, ending on $1^{\text {st }}$ December, 2014, the Court will have the same powers (with the exception of a few Member States) as regarding other areas of law. The legal effects of already adopted Framework Decisions, as long as they have not been amended, repealed or annulled, will continue to be the same as under the Amsterdam Treaty. This means, under the Pupino case law ${ }^{27}$, that national judicial and law enforcement authorities will have to interpret national legislation in conformity with the Framework Decisions (giving them "indirect effect").

It is too early yet to assess the impact of the incorporation of the Charter of Fundamental rights into the Treaty, but it may be noted that the Court in more than 30 judgments have already made reference to the Charter and that the Court has received 27 requests for preliminary rulings. This, combined with the possibility of adopting an urgency procedure, may in the not-so-distant future mean that the Court could become a Human Rights Court for the Union.

\section{From Amsterdam to Lisbon}

If one looks at the substance, in what areas of law has the Union acted? Does the Lisbon Treaty change anything when it comes to substantive law or procedural law?

Let me first recall what the Lisbon Treaty describes as a shared competence between the Union legislator and national legislators.

Under Article 83, the Union has competence to act in adopting Directives regarding substantive criminal law in "areas of particularly serious crime with a cross-border dimension resulting from the nature or impact of such offences or from a special need to combat them on a common basis". The Treaty then goes on to define the areas: "These areas are..."; and it is easy to note after a very cursory examination that the areas are a mixture of political, criminological and legal terms which some have questionable cross-border dimensions (although that term is deliberately chosen to give a greater margin of appreciation than that found in the civil law Chapter of the Treaty, which gives a more precise notion of cross-border "implications").

To give but just some examples: what is meant by the terms "organised crime", "corruption" or "terrorism"? Where is the cross-border dimension in many offences of corruption, sexual exploitation of children or money laundering? Does the Union have powers to criminalise counterfeiting of other means of payment than

\footnotetext{
${ }^{26}$ C-105/03, Pupino (Judgment of 16 June, 2005)
} 
the euro? Many of the definitions are also overlapping with the more general "organised crime" term.

In the area of procedural law, the Union has the power to approximate "mutual admissibility of evidence between Member States". (Why "mutual"? Either evidence is admissible or not? And why "admissibility of evidence between Member States"? Should we have special rules on admissibility of evidence collected abroad in our procedural codes? The principle of reciprocity is, at least not under Community law, a valid principle for the Union).

The Union can also approximate rights of individuals in criminal procedure which does not "prevent Member States from maintaining or introducing a higher level of protection for individuals". Why was it necessary to specify this in the Treaty since it speaks about "minimum rules" in any event? It must mean that in other areas the minimum rules are not so minimum after all. Are they maximum rules, then?

The Union can also approximate the rights of victims of crime, as it had already done so under the Amsterdam Treaty.

These three areas of procedural law are all prefaced by the rule that the Union's competence is subject to the condition that it is "to the extent necessary to facilitate mutual recognition of judgments and judicial decisions and police cooperation and judicial cooperation in criminal matters having a cross-border dimension". The Treaty then goes on, however, to provide that these three areas "shall concern" which seems to indicate that for those areas it would not be necessary to demonstrate the criterion of necessity in the chapeau of the text. One would otherwise have to question the Union competence for approximation of purely national law in these three areas (unless the legislator believes that we should have two sets of procedural codes).

When it comes to other procedural decisions, the Union's competence becomes even broader and subject to different interpretations. In this area, the Union may also adopt Regulations and not only Directives. These areas are "rules and procedures for ensuring recognition throughout the Union of all forms of judgments and judicial decisions", to "prevent and settle conflicts of jurisdiction", to "support the training of the judiciary and judicial staff" and to "facilitate cooperation between judicial or equivalent authorities of the Member States in relation to proceedings in criminal matters and the enforcement of decisions".

There are obviously a number of possible interpretations in relation to these provisions. The Legal Services of the Council, the Commission and the European Parliament will not be without employment in the future. The role of the Court of Justice will naturally become crucial in this regard. Will the Court, in this sensitive area, take a narrow interpretation or will it, as it has done previously in environment cases, take a relatively broad approach?

What does, for instance, "judicial decisions" mean? Do they include decisions made by Prosecutors? Is this also true for Member States where Prosecutors are directly dependent on Ministers of Justice? What is to "prevent" and "settle" conflicts of jurisdiction? Does the Union have the possibility to give to an external 
body such as Eurojust the power to take binding decisions on where a prosecution should take place or to make an injunction to a national prosecution service to prosecute in a case of negative conflict of jurisdiction? What is the relationship between this provision and Article 85:1 (c) which gives the possibility for the Union legislator to give the power to Eurojust to resolve conflicts of jurisdiction? How does the Union "support" training of the judiciary, and what constitutes "judiciary staff"? Do they encompass private practicing lawyers or not? We would probably not find many lawyers that would consider themselves to be "staff", albeit there are probably many that would like to be able to be eligible for the financial programmes of the Union.

An issue that has not been settled under the Lisbon Treaty - it may take decades to do this before the Court of Justice pronounces itself - is whether the "old" caselaw of the Court relating to environment still applies under the Lisbon Treaty. Or, put differently, is it still possible to adopt criminal law under the provisions of the Lisbon Treaty dealing with the former first pillar (e.g. on the environment) or must the Union legislator always have recourse to a legal basis under Chapter 4 of Title V of the Treaty (dealing with judicial cooperation in criminal matters) where the optins for the UK and Ireland would apply, where Denmark would (at least for the time being) be totally out of any decision-making and where the emergency brake would apply?

This is an issue which is not totally devoid of interest as the Commission may in the near future propose legislation relating to the protection of the financial interests of the Union, probably a "Lisbonisation" of the Maastricht Conventions in the socalled "PIF" area. What will happen, as it seems that it will, if the Commission proposes its new Directive (or Regulation?) under Article 325:4 TFEU? Can substantive criminal law be adopted through Regulations? There is case-law that seems to indicate that this is not possible. Has this been changed with the Lisbon Treaty? Is it compatible with Union principles of legal certainty? Probably not.

A final remark on the Treaty; the Union can always, through a simplified procedure under Article 82:2 (d) and Article 83:1, $3 \mathrm{~d}$ paragraph, enlarge its competences. This would require a unanimous decision by the Council and a consent procedure with the European Parliament. Under national law (and decisions by Constitutional Courts) it would also require primary legislation by parliaments - thus would probably take some 12 months to pass (in a best case scenario). Lisbon may have simplified things, but not everywhere.

\section{Has Lisbon restricted the competence of the Union?}

After having asked these questions relating to the Lisbon Treaty, let us revert to the question that was posed initially: does the Lisbon Treaty change anything compared with the Amsterdam Treaty (where most professionals agree that the substantive criminal law competence was an open competence - it was not conferred, it was not shared, the principle of pre-emption did not apply, and, since all 
decisions were taken by unanimity, and as long as the Council kept within the limits of the objective of creating an Area of Freedom, Security and Justice, it had a wide margin of manoeuvre to adopt Framework Decisions and Decisions)? The Amsterdam Treaty was institutionalised intergovernmentalism at its best (or worst).

If one looks at the nearly 40 Framework Decisions and Directives that were adopted under the Amsterdam Treaty, what could have been adopted under Lisbon or even Maastricht and what could not, and in what manner? The question is legitimate, because the theory in the Convention Praesidium was that the draft Constitution would have to clearly delimit (and make narrower) the powers to adopt substantive criminal law compared to the Amsterdam Treaty.

Here is the author's assessment (taking into account that Resolutions and conclusions do not need a legal basis; sometimes Recommendations do, but this will not be taken into account in this article).

Article 82, paragraph 1 (regarding ensuring recognition, conflicts of jurisdiction, training, facilitation of cooperation and enforcement): all Framework Decisions regarding mutual recognition, i. e. on the EAW, freezing, financial penalties, confiscation orders, supervision of probation measures, enforcement of deprivation of liberty, EEW, taking account of convictions, in absentia proceedings, supervision measures. In addition, the following Framework Decisions would have also been able to be adopted under the Lisbon Treaty: conflicts of jurisdiction, simplifying the exchange of information and intelligence between law enforcement authorities (the so-called Swedish Framework Decision) and the one on exchange of information relating to criminal records (ECRIS). It should be noted that a number of other Decisions, mostly relating to exchange of information, would have been able to be adopted.

Article 82, paragraph 2 (regarding admissibility, rights of individuals, victims): in absentia should also be mentioned under this article as that Framework Decision also had the objective of strengthening individual rights. The only other Framework Decision relating to this article was the one on victims from $2001^{28}$, which led to the famous Pupino case. The attempts to agree a Framework Decision on procedural rights failed in 2007. A more limited Framework Decision on interpretation and translation was politically agreed during the Swedish Presidency in 2009, but it never entered into force because the Lisbon Treaty made it obsolete. It was later turned into the Directive on the same topic as measure A of the Roadmap for strengthening procedural rights of suspected or accused persons in criminal proceedings.

Article 83, paragraph 1 (about the 10 "Eurocrimes" mentioned above): Framework Decisions on combating sexual exploitation of children (later Lisbonised as a Directive), drugs trafficking, confiscation of proceeds and property, attacks against information systems (on its way to becoming Lisbonised), organised crime, trafficking in human beings (later Lisbonised as a Directive), counterfeiting of the Euro,

\footnotetext{
${ }^{27}$ Council Framework Decision 2001/220/JHA of 15 March, 2001, on the standing of victims in criminal proceedings [2001] OJ L 82, p. 1.
} 
counterfeiting of non-cash means of payment, money laundering and confiscation, corruption in the private sector, terrorism, prevention of terrorism, a penal framework to prevent the facilitation of unauthorised entry, transit and residence. It should be noted that there is no legal basis on racism and xenophobia for drawing up a Directive under the Lisbon Treaty under Article 83, first or second paragraph, in spite of the fact that combating racism and xenophobia is explicitly mentioned in Article 67:3 as being among the issues that should be prevented and combated. As racism and xenophobia is much wider than discrimination under Article 19 TFEU, no explicit legal basis exists that would encompass the full scope of the 2008 Framework Decision $^{29}$. It is likely that this Framework Decision will remain untouched as consent is needed to reopen negotiations.

Article 83:2 (already harmonised areas): the question which has to be asked in this context is whether the case-law under the Amsterdam Treaty still stands or if Article 83:2 has become an exclusive legal basis for the adoption of criminal law. Viewpoints differ in Brussels and other capitals on this issue, where most capitals believe that the Article is exclusive and where some persons in the Institutions believe that environment criminal law is still relevant. There are as always arguments that are pro and contra. If it is necessary to enforce a primary aim of the Union, why should the legal basis in the old Community Treaty still not apply? What happens if the proposal is in relation to an area which cannot be seen as a harmonised area but which is proposed to be harmonised in a Directive? Yet on the other hand, if the governments and parliaments have created the legal basis for already harmonised areas, why should the Union legislator not use it?

In a recent proposal, the Commission has proposed a Regulation on market abuse, containing administrative sanctions and a Directive containing criminal sanctions. Here, the legal basis for the Directive for the first time is proposed to be Article 83:2. These two proposals raise various interesting questions, such as the issue of double jeopardy (ne bis in idem) and the right not to incriminate oneself. Negotiations have just begun.

It is also expected that the Commission will propose to Lisbonise the so-called PIF Conventions, i. e. the Conventions for the protection of the financial interests of the Union ${ }^{30}$ from the mid-1990s. The Commission may, in this case, choose to use Article 325 as the legal basis and the question will no doubt come up as to why Article 83:2 has not been chosen. The same would go for the Directives on environmental crime, ship-source pollution, data retention and illegal entry if changes were to be made in these. One may also wonder what the legal basis would be for the Directive on the right of compensation for victims of crime. When it was adopted in 2004, the legal basis was Article 308. Would not Article 83:2 be a more appropriate legal basis than the Lisbon Treaty corresponding provision, Article 352,

\footnotetext{
${ }^{28}$ Council Framework Decision 2008/913/JHA of 28 November, 2008, on combating certain forms and expressions of racism and xenophobia by means of criminal law [2008] OJ L 328, p. 55.

${ }^{29}$ Council Act of 26 July, 1995, drawing up the Convention on the protection of the European Communities' financial interests, [1995] OJ C 316, p. 48.
} 
since it would involve the European Parliament in the decision-making process and not only as a consultative body?

The conclusion of this is that in principle all Framework Decisions and Directives adopted under the Amsterdam Treaty could also have been adopted under the Lisbon Treaty, with the exception of the Framework Decision on racism and xenophobia, strangely enough, since the fight against this phenomenon is basically an objective of the Treaty itself. The real advance of the Treaty in the field of legal basis is Article 83:2, where the legislator has sought to resolve decades of litigation, probably not very successfully since the discussion still continues.

\section{Lisbon two years after}

It can now be concluded after a two-year trial period that the first results under the Lisbon Treaty have been encouraging. The Union legislator has agreed Directives on trafficking in human beings, on sexual exploitation of children, on translation and interpretation in criminal proceedings and on the right of information in criminal proceedings (measures A and B of the Roadmap). Discussions have been concluded in the Council on the victims' Directive and on the European Investigation Order (EIO). Discussions are well under way in the Council on the Directive on PNR (passengers' name records) and on access to a lawyer (measure $\mathrm{C}$ of the Roadmap). New and important proposals are expected on data protection, on confiscation, on protection of the financial interests of the Union and on drugs trafficking, among other things.

The Stockholm Programme, adopted under the Swedish Presidency of the Council of the EU, requested the Commission to come up with some 170 measures during the period in the entire JHA area. A number of them concern criminal law and the development of an area of justice in the Union. Combined with the development of mutual trust, through practical cooperation, through financial programmes, through training of actors in the area and through legislation, the Union will no doubt continue to give added value to Member States' cooperation in the area, while fully respecting Article 67 of the Treaty, fundamental rights and the Member States' legal systems and traditions. 